ORIGINAL PROF-2106

\title{
TYPE 2 DIABETES MELLITUS;
}

\author{
Dental caries in patients.
}

Dr. Ghulam Hussain Baloch, Dr. Abdul Qadir Dall, Dr. Atif Sitwat Hayat, Dr. Syed Zulfiquar Ali Shah, Prof. Bikha Ram Devrajani

ABSTRACT... Objective: To determine the frequency and pattern of dental carries in patients with type 2 diabetes mellitus. Design: Cross sectional descriptive study. Patients and methods: Patients with history of type 2 diabetes mellitus for $\geq 02$ years duration with $\geq 35$ years of age and of either gender with dental pain visit at medical and dental outpatient department (OPD) of Liaquat University Hospital Hyderabad. The detail history was taken and the blood samples were taken for haemoglobin $\mathrm{A} 1 \mathrm{c}(\mathrm{HbA1c})$ to assess the glycemic status. The existence of dental carries and its pattern was diagnosed through dental examination by consultant dentist had clinical experience $\geq 05$ years. The data was collected on pre-designed proforma, entered and analyzed in SPSS version 11.00. Results: A total of 137 type 2 diabetic patients were selected for this study, out of these 82 were males and 55 females. The dental carries was found in 98 (71.5\%) patients. Out of these ninety eight, 53 (54.08\%) were males and 45 (45.92\%) were female. Upper molar teeth involvement was present in 46 patients and lower molar teeth were involved in 52 patients. Dentine carries was seen in 35 patients, enamel carries in 19, white spot carries in 20 patients, pulpitis in 16 patients, and pulp capping in 8 patients. Involvement of individual teeth was also assessed, the upper molar involvement was present in 32 patients, premolar involvement was present in 11, incisor involvement in 03 patients. The lower molars were involved in 28 patients, lower pre molar in 21 and lower incisors in 03 patients. Dental carries was present in 43 (43.9\%) patients in patients whose duration of diabetes was between 5-10 years, whereas those patients having duration $>10$ years had $31.6 \%$ frequency of dental carries, while regarding duration of $<5$ years only $24(24.5 \%)$ patients had dental carries. Conclusions: The diabetic patients are more prone to acquire dental caries.

Key words: Diabetes mellitus, Dental carries, type 2 diabetes mellitus

Article Citation

Baloch GH, Dall AQ, Hayat AS, Shah SZA, Devrajani BR. Type 2 diabetes mellitus; Dental caries in patients. Professional Med J 2013;20(2): 237-243.

\section{INTRODUCTION}

Diabetes is a chronic disease, which occurs when the pancreas does not produce enough insulin, or when the body cannot effectively use the insulin it produces ${ }^{1}$. There are an estimated 23.6 million people in the U.S. (7.8\% of the population) with diabetes and 17.9 million being diagnosed, ${ }^{2} 90 \%$ of whom are type $2^{3}$. With prevalence rates doubling between 1990 and 2005, CDC has characterized the increase as an epidemic ${ }^{4}$. Pakistan is estimated to have 7 million people with diabetes. Currently it is 8th in the world according to WHO estimation of prevalence of diabetes and by the year 2025 is expected to be 4th with 15 million people with diabetes, representing a 2 fold increase in caseload $^{5}$. It is also one of the most common chronic diseases affecting children with about 200 children world-wide develop type 1 diabetes every day ${ }^{6}$. Diabetes is a leading cause of morbidity and mortality in Pakistan. Shera et al have shown prevalence of diabetes in the urban versus the rural areas was $6.0 \%$ in men and $3.5 \%$ in women against $6.9 \%$ in men and $2.5 \%$ in women, respectively. Newly diagnosed diabetes was $5.1 \%$ in men and $6.8 \%$ in women in urban areas and $5.0 \%$ in men and $4.8 \%$ in women in rural areas ${ }^{7}$.

Changed oral environment may cause increase in pathogenic bacteria and cause destruction of hard and soft tissues of mouth leading to cariogenic and gingival lesions ${ }^{8}$. Other common oral problems associated with diabetes include xerostomia, salivary gland dysfunction, increased susceptibility to bacterial, viral and fungal infection, periapical abscesses, loss of teeth, taste impairment, lichen planus, burning mouth syndrome and altered orthodontic tooth movements. These findings are associated with excessive loss of fluids due to polyuria, altered response to infection, altered 
connective tissue metabolism, micro vascular changes and impaired saliva ${ }^{9}$. When the normal environment of the oral cavity is altered because of a decrease in salivary flow or alteration in salivary composition, a healthy mouth can become susceptible to dental caries and tooth deterioration. An increase in the rate of dental caries has been reported in young patients with diabetes and may relate to salivary dysfunction ${ }^{10}$. Nonetheless, an association existed between older adults with diabetes and active caries and tooth loss; this was even more significant in patients with diabetes having poor glycemic control ${ }^{11}$. This study was conducted in type 2 diabetic population visit to dental OPD at tertiary care teaching hospital. Early evaluation and appropriate treatment can save the patient to acquire various complications.

\section{PATIENTS AND METHODS}

This cross sectional descriptive study was conducted in medical and dental outpatient department at Liaquat University Hospital Hyderabad from August 2011 to January 2011 on the patients with history of diabetes mellitus for $\geq 2$ years duration attending the medical OPD as follow up visit. The inclusion criteria for the study were patient $\geq 35$ years of age, known cases of diabetes mellitus (type2) present with dental pain, of either gender or patients who were agree and ready to give consent for participation in the study. The patients with improper history about missed tooth due to any cause, having habits of chewing pan, betel leaves, gutka or any other habits like these and patients with any inflammatory or febrile illness were considered in exclusion criteria.

A written consent was taken from all patients for participation in the study and all such patients who met the inclusion criteria were further had oral cavity examination by dental surgeon had clinical experience of $\geq 05$ years duration. The examination was done with the assistance of dental surgeon under the good light and with all necessary instruments like dental probe and dental mirror etc. The diagnosis of dental caries was made through a comprehensive assessment of all patient information by a visual examination of tooth surfaces. A dental probe or explorer was used to provide tactile information ${ }^{12-14}$. Caries in between adjacent teeth were visualized using bitewing radiographs or using light sources via transillumination. Caries diagnosis is based principally on clinical examination and review of radiographs ${ }^{14}$. The carries was considered to be present when any lesion had a detectable softened floor, undermined enamel and softened walls. The lesion must be clearly visible and probe point must have entered into the lesion with certainty. Regarding ethical justification, all the expenses of the study were paid by the cooperation of whole research team. The frequency and percentage was calculated for dental carries in diabetes mellitus type 2 as well as for gender distribution. The chi-square test was applied between categorical variables at 95\% confidence interval and the $p$-value $\leq 0.05$ was considered as statistically significant.

\section{RESULTS}

A total of 137 type 2 diabetic patients were selected for this study, out of these 82 were males and 55 females. The mean age \pm SD of patients was $42.63 \pm 5.73$. The dental carries was found in $98(71.5 \%)$ patients shown in Table 0l. Out of these 98 a total of 53 (54.08\%) were males and 45 (45.92\%) were female. Upper molar teeth involvement was present in 46 patients (30 male and 16 female) and lower molar teeth were involved in 52 patients (23 males and 29 females) respectively shown in Table II. We also assessed the stages of dental carries in all patients, dental carries was seen in 35 patients, enamel carries in 19, white spot carries in 20 patients, pulpitis in 16 patients, and pulp capping in 08 patients shown in Table-III.

Involvement of individual teeth was also assessed, the upper molar involvement was present in 32 patients (25 male and 07 female), pre molar involvement was present in 11 (03 males and 08 females) and upper 
incisor involvement in 03 (01 female and 02 males) shown in Table-IV. The lower molars were involved in 28 (8 male and 20 females) patients, lower pre molar in 21 (13 male and 08 females) and lower incisors in 3 (02 male and 01 female) shown in Table-V. We also assessed the relationship between the presence of dental carries and duration of diabetes mellitus. Dental carries was present in $43(43.9 \%)$ patients in patients whose duration of diabetes was between 5-10 years, whereas those patients having duration $>10$ years had $31.6 \%$ frequency of dental carries while the duration of $<5$ years, only $24(24.5 \%)$ patients had dental carries shown in Table-VI. The HbA1c was raised in 79 patients, of which $29(36.7 \%)$ had duration of diabetes for less than 05 years, forty two $(53.2 \%)$ patients had duration of diabetes for 05-10 years and $08(10.1 \%)$ had duration of diabetes for $>10$ years as shown in Table-VII. The relationship between dental carries and $\mathrm{HbA} 1 \mathrm{c}$ is shown in Table-VIII.

\begin{tabular}{|c|c|c|c|c|}
\hline & \multicolumn{2}{|c|}{ Gender } & \multirow[t]{2}{*}{ Total } & \multirow[t]{2}{*}{ P-value } \\
\hline & Male & Female & & \\
\hline \multicolumn{5}{|c|}{ Dental caries } \\
\hline Yes & $53(64.9 \%)$ & $45(81.8 \%)$ & $98(71.5 \%)$ & \multirow{3}{*}{$0.02^{*}$} \\
\hline No & $29(35.4 \%)$ & $10(18.2 \%)$ & $39(28.5 \%)$ & \\
\hline Total & $82(100 \%)$ & $55(100 \%)$ & $137(100 \%)$ & \\
\hline
\end{tabular}

\begin{tabular}{|c|c|c|c|c|}
\hline & \multicolumn{2}{|c|}{ Gender } & \multirow[t]{2}{*}{ Total } & \multirow[t]{2}{*}{ P-value } \\
\hline & Male & Female & & \\
\hline \multicolumn{5}{|l|}{ Teeth } \\
\hline Upper & $30(56.6 \%)$ & $16(35.6 \%)$ & $35(35.7 \%)$ & \multirow{3}{*}{$0.03^{*}$} \\
\hline Lower & $23(43.4 \%)$ & $29(64.4 \%)$ & $52(53.1 \%)$ & \\
\hline Total & $53(100 \%)$ & $45(100 \%)$ & $98(100 \%)$ & \\
\hline
\end{tabular}

\begin{tabular}{|c|c|c|c|c|}
\hline & \multicolumn{2}{|c|}{ Gender } & \multirow[t]{2}{*}{ Total } & \multirow[t]{2}{*}{ P-value } \\
\hline & Male & Female & & \\
\hline \multicolumn{5}{|l|}{ Stage } \\
\hline $\begin{array}{l}\text { Dentine } \\
\text { carries }\end{array}$ & $\begin{array}{c}23 \\
(43.4 \%)\end{array}$ & $\begin{array}{c}12 \\
(26.7 \%)\end{array}$ & $\begin{array}{c}35 \\
(35.7 \%)\end{array}$ & \multirow{6}{*}{$0.03^{*}$} \\
\hline $\begin{array}{l}\text { Enamel } \\
\text { carries }\end{array}$ & $\begin{array}{c}05 \\
(9.4 \%)\end{array}$ & $\begin{array}{c}14 \\
(31.1 \%)\end{array}$ & $\begin{array}{c}19 \\
(19.4 \%)\end{array}$ & \\
\hline $\begin{array}{l}\text { White spot } \\
\text { carries }\end{array}$ & $\begin{array}{c}09 \\
(17 \%)\end{array}$ & $\begin{array}{c}11 \\
(24.4 \%)\end{array}$ & $\begin{array}{c}20 \\
(20.4 \%)\end{array}$ & \\
\hline Pulpitis & $\begin{array}{c}11 \\
(20.8 \%)\end{array}$ & $\begin{array}{c}05 \\
(11.1 \%)\end{array}$ & $\begin{array}{c}16 \\
(16.3 \%)\end{array}$ & \\
\hline $\begin{array}{l}\text { Pulp } \\
\text { capping }\end{array}$ & $\begin{array}{c}05 \\
(9.4 \%)\end{array}$ & $\begin{array}{c}03 \\
(6.7 \%)\end{array}$ & $\begin{array}{c}08 \\
(8.2 \%)\end{array}$ & \\
\hline Total & $\begin{array}{c}53 \\
(100 \%)\end{array}$ & $\begin{array}{c}45 \\
(100 \%)\end{array}$ & $\begin{array}{c}98 \\
(100 \%)\end{array}$ & \\
\hline
\end{tabular}

\begin{tabular}{|c|c|c|c|c|}
\hline & \multicolumn{2}{|c|}{ Gender } & \multirow[t]{3}{*}{ Total } & \multirow[t]{3}{*}{ P-value } \\
\hline & \multirow[t]{2}{*}{ Male } & \multirow[t]{2}{*}{ Female } & & \\
\hline $\begin{array}{l}\text { Upper teeth } \\
\text { caries }\end{array}$ & & & & \\
\hline \multirow[t]{2}{*}{ Molar } & 25 & 07 & 32 & \multirow{8}{*}{$<0.01^{*}$} \\
\hline & $(83.3 \%)$ & $(43.8 \%)$ & $(69.6 \%)$ & \\
\hline \multirow[t]{2}{*}{ Premolar } & 03 & 08 & 11 & \\
\hline & $(10 \%)$ & $(50 \%)$ & $(23.9 \%)$ & \\
\hline \multirow[t]{2}{*}{ Incisor } & 02 & 01 & 03 & \\
\hline & $(6.7 \%)$ & $(6.3 \%)$ & $(6.5 \%)$ & \\
\hline \multirow[t]{2}{*}{ Total } & 30 & 16 & 46 & \\
\hline & (100\%) & $(100 \%)$ & $(100 \%)$ & \\
\hline \multicolumn{5}{|c|}{$\begin{array}{l}\text { Table-IV. Pattern of upper tooth caries in relation } \\
\text { to gender } \\
{ }^{*} P \text {-value is statistically significant }\end{array}$} \\
\hline
\end{tabular}




\begin{tabular}{|c|c|c|c|c|}
\hline & \multicolumn{2}{|c|}{ Gender } & \multirow[t]{2}{*}{ Total } & \multirow[t]{2}{*}{ P-value } \\
\hline & Male & Female & & \\
\hline \multicolumn{5}{|c|}{ Lower tooth caries } \\
\hline Molar & $\begin{array}{c}08 \\
(34.8 \%)\end{array}$ & $\begin{array}{c}20 \\
(69.0 \%)\end{array}$ & $\begin{array}{c}28 \\
(53.8 \%)\end{array}$ & \multirow{4}{*}{$0.04^{*}$} \\
\hline Premolar & $\begin{array}{c}13 \\
(56.5 \%)\end{array}$ & $\begin{array}{c}08 \\
(27.6 \%)\end{array}$ & $\begin{array}{c}21 \\
(40.4 \%)\end{array}$ & \\
\hline Incisor & $\begin{array}{c}02 \\
(8.7 \%)\end{array}$ & $\begin{array}{c}01 \\
(3.4 \%)\end{array}$ & $\begin{array}{c}03 \\
(5.8 \%)\end{array}$ & \\
\hline Total & $\begin{array}{c}23 \\
(100 \%)\end{array}$ & $\begin{array}{c}29 \\
(100 \%)\end{array}$ & $\begin{array}{c}52 \\
(100 \%)\end{array}$ & \\
\hline \multicolumn{5}{|c|}{$\begin{array}{l}\text { Table-V. Pattern of lower teethe caries in relation to } \\
\text { gender } \\
\star P \text {-value is statistically significant }\end{array}$} \\
\hline
\end{tabular}

\begin{tabular}{|c|c|c|c|c|}
\hline & \multicolumn{2}{|c|}{ HbA1c } & \multirow[t]{2}{*}{ Total } & \multirow[t]{2}{*}{ P-value } \\
\hline & Raised & Normal & & \\
\hline \multicolumn{5}{|c|}{ Duration (yrs) } \\
\hline$<05$ & $\begin{array}{c}29 \\
(36.7 \%)\end{array}$ & $\begin{array}{c}18 \\
(31.0 \%)\end{array}$ & $\begin{array}{c}47 \\
(34.3 \%)\end{array}$ & \multirow{4}{*}{$<0.01^{\star}$} \\
\hline $5-10$ & $\begin{array}{c}42 \\
(53.2 \%)\end{array}$ & $\begin{array}{c}11 \\
(19.0 \%)\end{array}$ & $\begin{array}{c}53 \\
(38.7 \%)\end{array}$ & \\
\hline$>10$ & $\begin{array}{c}08 \\
(10.1 \%)\end{array}$ & $\begin{array}{c}29 \\
(50.0 \%)\end{array}$ & $\begin{array}{c}37 \\
(27.0 \%)\end{array}$ & \\
\hline Total & $\begin{array}{c}79 \\
(100 \%)\end{array}$ & $\begin{array}{c}58 \\
(100 \%)\end{array}$ & $\begin{array}{c}137 \\
(100 \%)\end{array}$ & \\
\hline
\end{tabular}

Table-VII. The relationship between duration of diabetes and hba1c in patients with type 2 diabetes mellitus ${ }^{*} P$-value is statistically significant

\begin{tabular}{|c|c|c|c|c|}
\hline & \multicolumn{2}{|c|}{ Dental carries } & \multirow[t]{2}{*}{ Total } & \multirow[t]{2}{*}{ P-value } \\
\hline & Yes & No & & \\
\hline \multicolumn{5}{|c|}{ Duration (yrs) } \\
\hline$<05$ & $\begin{array}{c}24 \\
(24.5 \%)\end{array}$ & $\begin{array}{c}23 \\
(59.0 \%)\end{array}$ & $\begin{array}{c}47 \\
(34.3 \%)\end{array}$ & \multirow{4}{*}{$<0.01^{\star}$} \\
\hline $5-10$ & $\begin{array}{c}43 \\
(43.9 \%)\end{array}$ & $\begin{array}{c}10 \\
(25.6 \%)\end{array}$ & $\begin{array}{c}53 \\
(38.7 \%)\end{array}$ & \\
\hline$>10$ & $\begin{array}{c}31 \\
(31.6 \%)\end{array}$ & $\begin{array}{c}06 \\
(15.4 \%)\end{array}$ & $\begin{array}{c}37 \\
(27.0 \%)\end{array}$ & \\
\hline Total & $\begin{array}{c}98 \\
(100 \%)\end{array}$ & $\begin{array}{c}39 \\
(100 \%)\end{array}$ & $\begin{array}{c}137 \\
(100 \%)\end{array}$ & \\
\hline & $\begin{array}{l}\text { The dent } \\
{ }^{*} P \text {-value }\end{array}$ & $\begin{array}{l}\text { aries in r } \\
\text { diabetes } \\
\text { tatisticalls }\end{array}$ & $\begin{array}{l}\text { tion to do } \\
\text { gnificant }\end{array}$ & ion of \\
\hline
\end{tabular}

\begin{tabular}{|c|c|c|c|c|}
\hline & \multicolumn{2}{|c|}{ HbA1c } & \multirow[t]{2}{*}{ Total } & \multirow[t]{2}{*}{ P-value } \\
\hline & Raised & Normal & & \\
\hline \multicolumn{5}{|c|}{ Dental carries } \\
\hline Yes & $\begin{array}{c}64 \\
(81.0 \%)\end{array}$ & $\begin{array}{c}34 \\
(58.6 \%)\end{array}$ & $\begin{array}{c}98 \\
(71.5 \%)\end{array}$ & \multirow{3}{*}{$<0.04^{*}$} \\
\hline No & $\begin{array}{c}15 \\
(19.0 \%)\end{array}$ & $\begin{array}{c}24 \\
(41.4 \%)\end{array}$ & $\begin{array}{c}39 \\
(28.5 \%)\end{array}$ & \\
\hline Total & $\begin{array}{c}79 \\
(100 \%)\end{array}$ & $\begin{array}{c}58 \\
(100 \%)\end{array}$ & $\begin{array}{c}137 \\
(100 \%)\end{array}$ & \\
\hline
\end{tabular}

\section{DISCUSSION}

Dental caries and salivary factors have attracted less interest, and the results are divergent as to whether caries risk is different or salivary factors are affected in diabetic patients. Equal caries rates in diabetic patients and controls have been reported in many studies, ${ }^{5,16} \mathrm{a}$

higher caries risk among diabetic patients than healthy controls has also been demonstrated $d^{17,18}$.

The present study revealed that glucose levels was higher in diabetic patients with dental carries and their $\mathrm{HbA} 1 \mathrm{c}$ was also raised given an evidence of persistent raised blood sugar level, the finding is consistent with the study by lqbal, et al ${ }^{19}$. The differences in oral health between patients with diabetes and non diabetic subjects have been intensively studied. Widespread 
agreement exist about the increased risk for dental caries among patients with diabetes, although this view has not been supported unanimously, some authors have estimated that the risk of dental caries is about 3 folds in patients with diabetes compared to non diabetics, but these results have been obtained from type 2 study populations and may not be generalized, ${ }^{20}$ the same observation is also appeared in the present study.

In our study, the dental caries was predominant in molar tooth in both upper (69.6\%) and lower (53.8\%) teethes of patients with diabetes mellitus, the observation is consistent with the study published in $2008^{21}$. Few studies have documented that the difference between diabetic and control subjects with respect to dental caries may not be evident until the age of 30 to 40 years ${ }^{22,23}$.

In current series the mean age of population was 42.63 \pm 5.73 whereas Karjalainen, et al compared the diabetic patients with controls in ten years age subgroups between 40 and 70 years and was reported that dental caries began earlier in diabetics than in control and that the difference were most obvious in the age group or 40 to 49 years ${ }^{24}$. The role of diabetes as a predisposing or modifying factor with respect to the intensity of the host response initiated by local etiology has been confirmed, it was found that the accumulation of plaque was faster and its microbiological composition was different in diabetic then control. Diabetic patients have more microorganism colonies in their periodontal pockets. Poor glycemic control is strongly associated with dental caries. As it was show by a group of subjects with $\mathrm{HbA1C}>8.5$, the presence of dental caries was more distinctly associated with higher level of streptococcus mutans and lactobacilli than the group of subjects with $\mathrm{HbA} 1 \mathrm{c}<8.5^{25}$. The reducing effect of glucose on collagen synthesis by odontoblasts was established in vitro in a tissue culture system ${ }^{26}$. Glucose was observed to reduce the rate of collagen synthesis, which effect was independent of the insulin concentration in the culture medium ${ }^{26}$. Sugar reduced dentine formation in diabetic animals because of delayed wound healing and impaired collagen synthesis $^{27}$. Hyperglycemia, may reduce dentine opposition and aggravating caries progression, the preventive role of fluoride is that it inhibits sugar up take by microorganism ${ }^{28}$. Regarding staging, the majority of patients in present study had dentine (35.7\%) and enamels (19.4\%) caries. The process occurring inside the caries lesion in dentine is much more complicated than those occurring in the decalcified portion of the caries lesion in enamel. Papas, et al found that, in older adults, frequent consumption sugar was associated with the presence of more root surface caries, and that older adults with more root surface caries also reported to have higher total sugar and sticky sugar intake ${ }^{29}$. However, the relation between sugars and dental caries prevalence is dynamic, and there are other factors that may influence caries risk, such as fluoride exposure and eating patterns, among others, which may interact and affect caries development. We were unable to account for these factors in our study. In addition, dental caries is a chronic disease that may take years to develop.

Therefore, it is important to identify patients who may be at particularly high risk of dental caries. Diabetes mellitus, a significant public health problem in its own right, may increase one's susceptibility to dental caries. In addition, people with diabetes are also more prone to infections, including dental abscesses that result from progressive dental caries. Unfortunately, there is sparse longitudinal population-based data that would allow a temporal evaluation of the association between diabetes diagnosis and subsequent risk of dental caries. However, cross-sectional data may provide information regarding this relationship that may prove valuable for clinical practitioners to identify subpopulations at high risk of suboptimal oral health, such as a greater prevalence of severe dental caries among diabetic patients. 


\section{CONCLUSIONS}

Poor glycemic control and significantly increase value of $\mathrm{HbA1c}$ in diabetic patient is associated with more number of curious teeth. There is a need for frequent and periodic dental examination among the patients with type 2 diabetes mellitus with poor glycemic control. Regular dental check-ups for preventive measures such as fluoride therapy, fissure sealant, regular medical follow-ups for proper control of metabolic abnormalities to decrease the occurrence of xerostomia, omission of carcinogenic substances from the dietary regimen, fluorination of the drinking water, and individual and group education of diabetic patients regarding proper dental hygiene are strongly recommended.

Copyright@ 08 Jan, 2013.

\section{REFERENCES}

1. McPhee SJ, Papadakis MA. Diabetes mellitus and Hyperglycemia. In: Masharani U, editor. Current Medical Diagnosis \& Treatment. 49th ed. USA: Churchill Livingstone The McGraw-Hill Companies; 2010. p. 1079-1133.

2. Rother KI. Diabetes treatment-bridging the divide. N Engl J Med 2007;356 (15): 1499-501.

3. Holman RR, Paul SK, Bethel MA, Matthews DR, Neil HA 10-year follow-up of intensive glucose control in type 2 diabetes. N Engl J Med 2008;359(15):1577-89.

4. Jack B. Homer, PhD and Gary B. Hirsch, SM. System Dynamics Modeling for Public Health: Background and Opportunities. Am J Public Health. 2006;96(3): 452-458.

5. Alberti KG, Zimmet P, Shaw J. International Diabetes Federation: a consensus on Type 2 diabetes prevention. Diabet Med 2007;24(5):451-63.

6. Hakeem R, Fawwad A. Diabetes in Pakistan: Epidemiology, Determinants and Prevention. Journal of Diabetology.2010;3:1-4.

7. Shera AS, Jawad F, Maqsood A. Prevalence of diabetes in Pakistan. Diabetes Res Clin Pract.2007;76(2):219-22.
8. Aren G, Sepet E, Ozdemir D, Dinççağ N, Güvener B, Firatli $E$. Periodontal health, salivary status and metabolic control in children with type1 diabetes mellitus. J Periodontal.2003; 74:1789-95.

9. WHO/International diabetes federation. Launch of diabetes action now. $5^{\text {th }}$ May 2004, Geneva, Switzerland.

10. Twetman S, Nederfors T, Stahl B, Aronson S. Two-year longitudinal observations of salivary status and dental caries in children with insulin-dependent diabetes mellitus. Pediatr Dent 1992;14(3):184-8.

11. Lin BP, Taylor GW, Allen DJ, Ship JA. Dental caries in older adults with diabetes mellitus. Spec Care Dent 1999;19(1):8-14.

12. Ismail Al. Clinical diagnosis of precavitated carious lesions. Community Dent Oral Epidemiol.1997;25(1): 13-23.

13. Pitts NB. Diagnostic tools and measurements-impact on appropriate care. Community Dent Oral Epidemiol.1997;25(1):24-35.

14. Bader JD, Shugars DA, Bonito AJ. Systematic reviews of selected dental caries diagnostic and management methods. J Dent Educ. 2001;65(10): 960-8.

15. Ben-Aryeh H, Cohen M, Kanter Y, Szargel R, Laufer D. Salivary composition in diabetic patients. J Diabet Complications.1988;2:96-9.

16. Belazi MA, Galli-Tsinopoulou A, Drakoulakos D, Fleva A, Papanayiotou PH. Salivary alterations in insulindependent diabetes mellitus. Int J Paediatr Dent 1998;8:29-33.

17. Twetman S, Nederfors T, Stahl B, Aronson S. Two-year longitudinal observations of salivary status and dental caries in children with insulin-dependent diabetes mellitus. Pediatr Dent 1992;14:184-8.

18. Tenovuo J, Alanen P, Larjava H, Viikari J, Lehtonen OP. Oral health of patients with insulin dependent diabetes mellitus. Scand J Dent Res 1986; 94:338-46.

19. Iqbal S, Kazmi F, Asad S, Mumtaz M, Khan A. Dental caries \& diabetes mellitus. Pakistan Oral \& Dental 
Journal 2011;31(1):60-63.

20. Balakrishnan M, Simmonds RS, Tagg JR. Dental caries is a preventable infectious disease. Aust Dent $\mathrm{J}$. 2000;45(4):235-45.

21. Patiño Marín N, Loyola Rodríguez JP, Medina Solis CE, Pontigo Loyola AP, Reyes Macías JF, Ortega Rosado JC, et al. Caries, periodontal disease and tooth loss in patients with diabetes mellitus types 1 and 2 . Acta Odontol Latinoam. 2008;21(2):127-33.

22. Bacić M, Ciglar I, Granić M, Plancak D, Sutalo J. Dental status in a group of adult diabetic patients. Community Dent Oral Epidemiol. 1989;17(6):313-6.

23. Ryan ME, Carnu 0, Kamer A. The influence of diabetes on the periodontal tissues. J Am Dent Assoc. 2003;134 Spec No:34S-40S.

24. Lin BP, Taylor GW, Allen DJ, Ship JA. Dental caries in older adults with diabetes mellitus. Spec Care Dentist.1999;19(1):8-14.

25. Syrjälä AM, Niskanen MC, Ylöstalo P, Knuuttila ML.
AUTHOR(S):

1. DR. GHULAM HUSSAIN BALOCH

Associate Professor

Department of Medicine

Liaquat University of Medical \& Health Sciences, Jamshoro

2. DR. ABDUL QADIR DALL

Assistant Professor

Department of Dentistry

Liaquat University of Medical \& Health Sciences, Jamshoro

3. DR. ATIF SITWAT HAYAT

Assistant professor

Department of Medicine

Isra University Hyderabad
Metabolic control as a modifier of the association between salivary factors and dental caries among diabetic patients. Caries Res. 2003;37(2):142-7.

26. Välikangas L, Pekkala E, Larmas M, Risteli J, Salo T, Tjäderhane $L$. The effects of high levels of glucose and insulin on type I collagen synthesis in mature human odontoblasts and pulp tissue in vitro. Adv Dent Res. 2001;15:72-5.

27. Pekkala E, Välikangas L, Puukka M, Tjäderhane L, Larmas M. The effect of a high-sucrose diet on dentin formation and dental caries in hyperinsulinemic rats. J DentRes. 2002;81(8):536-40.

28. Larmas M. Dental caries seen from the pulpal side: a non-traditional approach. J Dent Res.2003;82(4): 253-6.

29. Papas AS, Joshi A, Palmer CA, Giunta JL, Dwyer JT. Relationship of diet to root caries. Am J Clin Nutr. 1995;61(2):423S-9S. Touger-Decker R, van Loveren C. Sugars and dental caries. Am J Clin Nutr.2003;78(4):881S-92S.
4. Dr. Syed Zulfiquar Ali Shah

Department of Medicine

Liaquat University of Medical \& Health Sciences, Jamshoro

5. Prof. Bikha Ram Devrajani

Incharge Medical unit-IV

Liaquat University of Medical \& Health Sciences, Jamshoro

Correspondence Address:

Dr, Syed Zulfiquar Ali Shah

House No. 279, Doctors' Colony Hirabad

Hyderabad, Sindh, Pakistan

zulfikar229@hotmail.com

Article received on: 22/10/2012 Accepted for Publication: $\quad$ 08/01/2012 Received after proof reading: $\quad 00 / 00 / 0000$

\section{PREVIOUS RELATED STUDIES}

Amena Rahim, Amir Shahzad. PIOGLITAZONE VS DLIMEPIRIDE; TO EVALUATE THE EFFECT OF ON RENAL FUNCTION TESTS IN TYPE 2 DIABETES IN PATIENTS (Original) Prof Med Jour 18(3) 450-453 Jul, Aug, Sep 2011.

Dilshad Muhammad, Khalid Amin, Amin Anjum, Masood Javed. CHRONIC HEPATITIS C VIRUS INFECTION; ASSOCIATION WITH TYPE 2 DIABETES MELLITUS (Original) Prof Med Jour 17(4) 557-562 Oct, Nov, Dec 2010.

Syed Shahjee Husain, Muhammad Rizwan Javed, Sara Ahmad Ali. DIABETIC KETOACIDOSIS; THE PRECIPITATING ENTITIES IN PATIENTS WITH TYPE 2 DIABETES MELLITUS (Original) Prof Med Jour 18(1) 82-82 Jan, Feb, Mar 2011.

Usman Khurshid, Ibrahim Us. SIALIC ACID AS A PREDICTOR OF TYPE 2 DIABETES MELLITUS (Original) Prof Med Jour 15(2) 273-280 Apr, May, Jun 2008. 